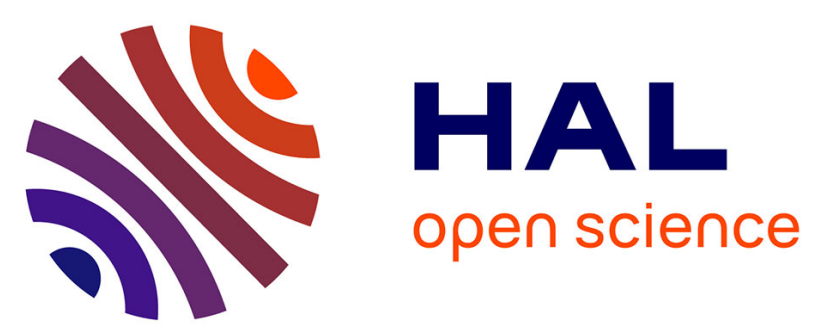

\title{
Tuning the Properties of Confined Water in Standard and Hybrid Nanotubes: an Infrared Spectroscopic Study
}

Yuanyuan Liao, Pierre Picot, Jean-Blaise Brubach, Pascale Roy, Antoine Thill, Sophie Le Caër

\section{- To cite this version:}

Yuanyuan Liao, Pierre Picot, Jean-Blaise Brubach, Pascale Roy, Antoine Thill, et al.. Tuning the Properties of Confined Water in Standard and Hybrid Nanotubes: an Infrared Spectroscopic Study. Matériaux 2018, Nov 2018, Strasbourg, France. 10.1016/j.clay.2017.1006.1005 cea-02327877

\section{HAL Id: cea-02327877 https://hal-cea.archives-ouvertes.fr/cea-02327877}

Submitted on 23 Oct 2019

HAL is a multi-disciplinary open access archive for the deposit and dissemination of scientific research documents, whether they are published or not. The documents may come from teaching and research institutions in France or abroad, or from public or private research centers.
L'archive ouverte pluridisciplinaire HAL, est destinée au dépôt et à la diffusion de documents scientifiques de niveau recherche, publiés ou non, émanant des établissements d'enseignement et de recherche français ou étrangers, des laboratoires publics ou privés. 


\section{Tuning the Properties of Confined Water in Standard and Hybrid Nanotubes: an Infrared Spectroscopic Study \\ Yuanyuan Liao ${ }^{a}$, Pierre Picot ${ }^{a}$, Jean-Blaise Brubach ${ }^{b}$, Pascale Roy ${ }^{b}$, Antoine Thilla and Sophie Le Caër $\mathrm{r}^{*}$}

a. LIONS, NIMBE, UMR 3685, CEA, CNRS, Université Paris-Saclay, CEA Saclay Bât. 546, F-91191 Gif-sur-Yvette Cedex, France

b. Synchrotron SOLEIL AILES Beamline, L'Orme des Merisier, Saint-Aubin, BP 48, F-91192, Gif-sur-Yvette Cedex, France

*sophie.le-caer@cea.fr

Imogolite is a natural nanotubular aluminum silicate clay mineral, originally found in volcanic soils. Its well-defined, yet tunable structure makes it a good candidate for the study of water confined in a one-dimensional structure. Water confined in imogolite selfsustaining thin films was studied by means of infrared spectroscopy [1]. Two types of synthetic imogolites were investigated: a pristine imogolite $(\mathrm{IMO}-\mathrm{OH})$ with a hydrophilic inner surface fully covered with Si-OH groups and a hybrid imogolite $\left(\mathrm{IMO}-\mathrm{CH}_{3}\right)$ with a hydrophobic inner surface fully covered with $\mathrm{Si}-\mathrm{CH}_{3}$ groups. Both imogolites have the same outer surface, covered with $\mathrm{Al}-\mathrm{OH}$ groups. The infrared spectra were recorded in the $20-4000 \mathrm{~cm}^{-1}$ spectral range as a function of the relative humidity. In particular, a detailed analysis of the $\mathrm{O}-\mathrm{H}$ stretching band provides information on the $\mathrm{H}$-bonding of confined water molecules inside and outside the IMO-OH tubes. The analysis of the various infrared signatures reveals the scenario for water filling as a function of relative humidity for the two systems. The adsorption in the $\mathrm{IMO}-\mathrm{OH}$ tubes starts at the lowest relative humidity $(<10 \%)$. The inner surface of the tubes is first covered with water molecules, followed by the filling-up of the central part of the tubes, leading to very strong $\mathrm{H}$-bonds and a structured spectrum. In contrast, the $\mathrm{H}$-bonds of water adsorbed at the outer surfaces of these tubes are weaker. A different scenario is evidenced for water inside $\mathrm{IMO}_{-} \mathrm{CH}_{3}$ : very weakly $\mathrm{H}$-bonded water molecules are present, a situation similar to what has been observed in carbon nanotubes. The present work shows that water confinement in imogolites is governed by the hydrophilicity of the inner walls. Indeed, at similar partial pressure, water can be less or more $\mathrm{H}$-bonded depending on its interactions with the nanotube wall [2].

[1] Y-Y. Liao, P. Picot, J.-B. Brubach, P. Roy, S. Le Caër and A. Thill, Self-supporting thin films of imogolite and inogolite-like nanotubes for infrared spectroscopy, Appl. Clay. Sci. (2017), https://doi.org/10.1016/j.clay.2017.1006.1005

[2] Y-Y. Liao, P. Picot, M. Lainé, J.-B. Brubach, P. Roy, A. Thill and S. Le Caër, Tuning the Properties of Confined Water in Standard and Hybrid Nanotubes: an Infrared Spectroscopic Study, Nano Research, in press. 